\title{
Nutritional ecology and digestive response to dietary shift in the large South American fox, Pseudalopex culpaeus
}

\author{
Ecología nutricional y respuesta digestiva a cambios en la dieta en el zorro \\ sudamericano grande, Pseudalopex culpaeus
}

SERGIO I. SILVA*, FABIÁN M. JAKSIC \& FRANCISCO BOZINOVIC

Center for Advanced Studies in Ecology \& Biodiversity, Pontificia Universidad Católica de Chile, Facultad de Ciencias Biológicas, Departamento de Ecología, Casilla 114-D, Santiago, Chile; *e-mail for corresponding author: ssilva@bio.puc.cl

\begin{abstract}
We tested the role of dietary shifts (from rodents to fruits and to mixed diets) on the nutritional ecology of the culpeo fox Pseudalopex culpaeus, a native canid of South America. We studied the effects of food quality on digestive processes, nutrition, and mass balance, and the implications of diet quality for fox survival. We observed at the end of the nutritional trials that body mass differed significantly between the three diet groups (fruits, rats and mixed diets), while percentage of body mass change differed significantly only in the fruit diet treatment. Foxes fed with fruits consumed more food to meet their dietary and metabolic needs. Across diets, dry-matter as well as energy digestibility increased significantly with diet quality. Also, mean retention time was negatively and significantly correlated with dry-matter intake. We put forth that mixed diet may yield higher assimilation efficiencies and hence higher nutrient intakes than those predicted from the ingestion and assimilation of pure diets (i.e,. only rats, only fruits). We hypothesize that during periods of low availability of mammalian prey, a mixed diet should yield a positive energy/mass balance for the fox. We conclude that temporal and spatial variation in nutrient, energy, and water contents of prey available in a given habitat could have an important effect on fox nutrition, energy use, and mass balance. Finally, we postulate that $P$. culpaeus could not survive on fruits only past seven days.
\end{abstract}

Key words: nutritional bottleneck, fox, dietary shift, fruit consumption.

\section{RESUMEN}

Sometimos a prueba el papel del cambio de dieta (desde roedores a frutos y dieta mixta) sobre la ecología nutricional del zorro culpeo Pseudalopex culpaeus, especie nativa de Sudamérica. Estudiamos el efecto de la calidad del alimento sobre los procesos digestivos, nutrición, balance de masas y las implicancias de la calidad de la dieta sobre la sobrevivencia de los zorros. La masa corporal al final de los ensayos nutricionales difirió significativamente entre los tres grupos de dietas (frutos, ratas y dieta mixta), en tanto que el porcentaje de cambio en masa corporal solo fue significativo en el caso de la dieta de frutos. Los zorros alimentados con frutos consumieron más alimento para satisfacer sus necesidades dietarias y metabólicas. Tanto la ingesta de materia seca como la digestibilidad se incrementaron significativamente con la calidad de la dieta. Más aún, el tiempo de retención promedio estuvo negativa y significativamente correlacionado con la ingesta de materia seca. Pensamos que la dieta mixta puede entregar mayores eficiencias de asimilación y por lo tanto mayores ingestas de nutrientes que lo predicho por la ingesta y asimilación de dietas puras (i.e., solo ratas, solo frutos). Proponemos la hipótesis que durante períodos de baja disponibilidad de presas (micromamíferos) una ingesta de dieta mixta podría entregar un balance energía/masa positivo para los zorros. Concluimos que la variación temporal y espacial de nutrientes, energía y contenido de agua presente en las presas disponibles en un determinado hábitat puede tener un importante efecto sobre la nutrición, uso de energía y balance de masa de los zorros. Finalmente, postulamos que $P$. culpaeus no puede sobrevivir con una dieta exclusivamente de frutos mas allá de siete días.

Palabras clave: cuello de botella nutricional, zorro, cambio dietario, consumo de frutos. 


\section{INTRODUCTION}

Fruit consumption by vertebrates often involves mutualistic interactions between plants and frugivores. The net result of frugivory is two-fold: fruit removal, which may or may not result in seed dispersal away from the parent (Herrera et al. 1994, Herrera 1998), and food acquisition, because fleshy fruits are packages containing not only seeds but also surrounding nutritive material. Thus, frugivores may obtain energy and nutrients as a result of digesting fruit pulp (Herrera 1984, 1987, Johnson et al. 1985, Rode \& Robbins 2000, Felicetti et al. 2003). Nevertheless, animal nutrition depends not only on food type but also on digestive strategies (i.e., Castro et al. 1989, Bozinovic 1995, Bozinovic \& Muñoz-Pedreros 1995a, 1995b, Sabat \& Bozinovic 2000, Ahlstrom et al. 2003). Comparatively low-quality, energy-diluted foods such as fruits have low digestibility (Bosque \& Pacheco 2000, Cipollini 2000). Therefore, to maintain an adequate energy/ matter budget while consuming fruits, the expected foraging behavior and digestion for fruit-eating vertebrates is an increase in the rate of food intake and a decrease in the digesta transit time (Levey \& Karasov 1989, Karasov \& Levey 1990, Levey \& Grajal 1991, Martínez del Río 1994). However, a critical point is eventually reached (critical digestibility, sensu Cork 1994) as a consequence of design constraints for utilization of low-quality foods. Theoretically, frugivores should compensate such constraints by behaviorally complementing their diet with high-quality though less abundant food items.

Fruit does not represent a high-quality food, but it is nonetheless consumed by different mammals (Ball \& Golightly 1992, McNab 1995, 2000, Welch et al. 1997, Kimball et al. 1998, Elmhagen et al. 2000). Westoby (1978) pointed out that individuals should consume a mixed diet (i.e., fruit + vertebrates) to respond to changes in diet quality, to reduce searching costs, to sample items, and to balance nutrient intake. Pennings et al. (1993) proposed that, if consumers attempt to maximize the intake of different nutrients simultaneously, and if different dietary items are sources of unstable limiting nutrients, then consumers might survive with just one item, but would obtain a better short-time success (energetic/ physiological or survivorship), and long-time success (reproductive) with a mixture of different items. Many carnivorous mammals commonly ingest fleshy fruits (Gittleman 1989). Nevertheless, the role of fruits on carnivore nutritional ecology and energetics has remained virtually unexplored (Vogtsberger \& Barret 1973, Moors 1977, Litvaitis \& Mautz 1980, Ball \& Golightly 1992, McNab 1995, 2000, Welch et al. 1997).

We studied the effect of an acute ingestion of Schinus molle (peppertree) fruits on the nutritional energetics of the culpeo fox Pseudalopex culpaeus. The culpeo fox is the second largest (6-8 kg) in South America (Ginsberg \& MacDonald 1990). Throughout its range of distribution it feeds on rodents and other small vertebrates, but it also feeds on fruits (Medel \& Jaksic 1988, Jaksic 1997). Out of 4,488 feces analyzed in semiarid Chile from September 1988 to January 2001, $12.4 \%$ contained only fruits, $32.0 \%$ contained fruit and vertebrates and $55.6 \%$ contained only vertebrates (Silva 2001). In addition, Silva et al. (2004) report what about 34,000 fruits were consumed, based on the number of seeds counted (17,267 g), Schinus molle representing $98 \%$ and all other species the remaining $2 \%$. Previously, Castro et al. (1994) reported for another area of northern Chile that peppertree fruits represent $82 \%$ of total fruits consumed. These two studies reported that maximum fruit consumption occurrs between April and August, a period of low availability of animal prey. The phytochemical database (2001) reports that peppertrees contain tannins, alkaloids, flavonoids, steroidal saponins, sterols, terpenes, gums, and essential oils, while their fruits are rich in triterpenes, sesquiterpenes and monoterpenes (see also Cipollini 2000).

We investigated the acute response of the culpeo fox fed with a rat diet (high-energy) or a mixed diet of rats and peppertree fruits (lowenergy) to asses the effect of food quality on digestive processes, nutrition and mass balance of the culpeo fox, and the implications of diet quality for fox survival. We hypothesized that variations in fox diet quality may not only reflect changes in food availability or foraging profitability, but also depend on the interplay between dietary chemistry and fox digestive 
processing capabilities. Because foxes do not indiscriminately feed on any food item they encounter, but feed preferentially on foods higher in certain nutritional/energetic compounds or lower in other components, we investigated experimentally the relationship between diet (fruit, rat and mixed diets), food chemistry, and nutrient assimilation.

\section{MATERIAL AND METHODS}

\section{Animals and diets}

Between May 1998 and June 2000, fifteen nonreproductive adult individuals of culpeo fox (nine males and six females), ranging in body mass from 4,480 to $6,140 \mathrm{~g}$ were captured in central Chile at Quebrada de la Plata $\left(33^{\circ} 31^{\prime} \mathrm{S}\right.$, $70^{\circ} 50^{\prime} \mathrm{W}$, elevation ranging 400 to $850 \mathrm{~m}$ ) and in northern Chile at Aucó ( $31^{\circ} 30^{\prime} \mathrm{S}, 71^{\circ} 06^{\prime} \mathrm{W}$, elevation ranging 400 to $1,700 \mathrm{~m}$ ). Five foxes were trapped during August 1998-December 1998 (three males and two females, assigned to rat diet), three in June 1999 (two males and one female, assigned to mixed diet), two in August 1999 (two males, assigned to mixed diet), three females in March 2000 (assigned to fruit diet) and two males in June 2000 (assigned to fruit diet). Treatments were designed according to the field diet of culpeo fox (Castro et al. 1994, Silva 2001). Foxes were caught using padded leg-hold traps (Victor Soft Catch No. 1.5, Chagnon's Trapping Supply, Manistique, Michigan, USA). Captured foxes were immobilized with Ketamine hydrochloride (0.1$0.2 \mathrm{ml} \mathrm{kg}^{-1}$ estimated body mass). Weight, age (estimated by tooth wear), and sex were recorded.

Foxes were transported in iron cages $(1.0 \mathrm{x}$ $1.0 \times 0.8 \mathrm{~m}$ ) to the laboratory on the day of capture. Animals were individually housed in iron cages $(2.0 \times 1.5 \times 1.0 \mathrm{~m})$ in an animal room $(4.0 \times 10.0 \times 2.5 \mathrm{~m})$. The fifteen foxes were maintained during the first four days on ground beef and water ad libitum with a photoperiod of $12 \mathrm{~L}: 12 \mathrm{D}$ and ambient temperature of $20{ }^{\circ} \mathrm{C}$. Five individuals per group were assigned to three experimental diets: live laboratory rats $\left(400 \mathrm{~g} \mathrm{day}^{-1}\right)$, peppertree fruits supplied ad libitum, and a mixed diet (proportion 1:4 of minced laboratory rats to peppertree fruits, supplied ad libitum) and maintained during ten days on each treatment. In sum, we had three different diets: (1) rat diet, with live laboratory rats; 10 days for five foxes. (2) Mixed diet, with minced laboratory rats and fruits; 10 days for five foxes. (3) Fruit diet, exclusively of peppertree fruit; 10 days for five foxes.

We used fruits of $S$. molle because Silva (2001) reported that this shrub represents $98 \%$ of total fruits consumed by this fox in our study areas. Food consumption was measured gravimetrically $( \pm 0.1 \mathrm{~g})$. To correct for evaporation, diets were left for the same length of time (10 days) in cages without animals and then weighed. Crude fiber, crude fat, crude protein and carbohydrate content of the diets and of feces was measured using proximal chemical analysis (AOAC 1980), while energy content was determined with a Parr 1261 computerized calorimeter. Three replicates were determined to be ash-free and were considered reliable when the difference between two measurements was smaller than 1 $\%$ (see Table 1 ).

\section{Nutritional trials}

To test whether diet quality correlates with digestibility, gut retention time, and body mass balance, we conducted nutritional. Fox individuals (five different for each diet) where kept in metabolic iron cages $1.6 \times 1.0 \times 0.8 \mathrm{~m}$ ) with metal trays underneath to collect their feces. Trials ran for ten days, supplying experimental food to each animal, and collecting feces and any food material not consumed. Feces and remaining food were collected, weighed and stored, after drying at $70{ }^{\circ} \mathrm{C}$ to constant weight. Digestibility (D) was calculated for each experimental diet and for dry-matter, nitrogen, and energy as: [(Qi - Qe $)$ / Qi] x $100 \%$, where Qi = daily rate of drymatter, nitrogen, or energy intake and $\mathrm{Qe}=$ daily rate of feces production (dry-matter, nitrogen, and energy). Digestible energy intake (DEI) was calculated as: Qi x D. Mean retention times for experimental foods were calculated as MRT $=\sum \mathrm{m}_{\mathrm{i}} \mathrm{t}_{\mathrm{i}} / \sum \mathrm{m}_{\mathrm{i}}$, where $\mathrm{m}_{\mathrm{i}}$ is the amount of marker excreted at the ith defecation at time $\mathrm{t}$ after dosing (Warner 1981, Torres-Contreras \& Bozinovic 1997, Bozinovic $\&$ Torres-Contreras 1998). We used one hundred $2-\mathrm{mm}^{2}$ commercial flagging tape that 
was homogenized with each experimental diet and then pelletized in small units $( \pm 80 \mathrm{~g})$.

One pellet was given to each animal, and the metabolic chamber was examined every 10 min to determine when feeding started. Subsequently, the cage was cleaned so that no marker remained, and the animal was given its experimental food ad libitum. Feces were collected at 2 -h intervals over the next two days; they were stored and then examined for the presence of marker particles. Body mass of foxes was determined at the beginning and at the end of each trial.

\section{Statistics}

Statistical analyses were performed using the STATISTICA (1997) statistical package for Windows 95. Data were analyzed with one-way ANOVA and Tukey test $(\alpha=0.05)$ for multiple comparisons. Results are reported as mean \pm SE.

\section{RESULTS AND DISCUSSION}

As expected, nutritional and energy content varied among diets (Table 1). Rats had higher water contents, ash and lipids than did fruits of $S$. molle. In addition, energy and nitrogen contents were significantly different between diets, being higher for rats and lower for fruits (Table 1). The chemical composition of rats was similar to previous reports (Karasov 1990,
Ball \& Gologhtly 1992), but our test fruit ( $S$. molle) had lower nitrogen content and higher energy and lipid contents than average values reported for other species (Landers et al. 1977, Ball \& Gologhtly 1992, Bosque \& Pacheco 2000). In addition, water content of fruits was lower than in rats.

After dietary treatments, body mass balance was positive in foxes fed with rat and mixed diets, and negative in individuals maintained exclusively with fruits (Table 2, Fig. 1). There were significantly differences between diets in dry-matter ingestion (Table 2). As expected, dry-matter intake of fruits was higher than the intake of rats and mixed diets. Energy intake was similar among diets, and a decreasing trend was observed in terms of nitrogen intake from rats to fruits (Table 2). Apparent digestibility was closely related to diet quality. Across diets, dry-matter as well as energy digestibility increased significantly with diet quality (Table 2). Nitrogen digestibility followed a negative trend. Non-significant differences in digestible intake energy were observed between diets (Table 2).

As expected, mean retention time was significantly shorter in foxes feeding on fruits and longer in those feeding on rats (Table 2). Foxes given fruits consumed more food to try to meet their dietary and metabolic needs. However, they no meet their metabolic needs and they lost weigh (Fig. 1). This has been shown for many mammals and birds (Foley \& Cork 1992).

TABLE 1

Chemical composition (\% of DM) and gross energy contents of diet $\left(\mathrm{kcal} \mathrm{g}^{-1}\right)$. Standard deviation in parentheses $(n=3)$

Composición química (\% de PS) y contenido energético de las dietas $\left(\mathrm{kcal} \mathrm{g}^{-1}\right)$. Desviación estándar entre paréntesis $(\mathrm{n}=3)$

\begin{tabular}{|c|c|c|c|c|c|}
\hline Composition & Rodent & Mixed & Fruit & $\mathrm{F}_{(2,6)^{- \text {value }}}$ & P-value \\
\hline Dry matter & $34.2(0.32)$ & $77.2(0.18)$ & $88.0(0.30)$ & 2320 & $<0.0001$ \\
\hline Ash & $6.3(0.09)$ & $5.7(0.07)$ & $5.5(0.08)$ & 73.67 & $<0.0001$ \\
\hline Crude fiber & $1.0(0.15)$ & $12.4(0,20)$ & $15.2(0.26)$ & 3766 & $<0.0001$ \\
\hline Crude fat & $31.0(0.10)$ & $16.0(0.19)$ & $12.3(0.25)$ & 7962 & $<0.0001$ \\
\hline Crude protein & $55.2(0.20)$ & $15.4(0.23)$ & $5.4(0.25)$ & 40249 & $<0.0001$ \\
\hline Carbohydrate & $6.5(0.47)$ & $50.6(0.59)$ & $61,6(0.73)$ & 6960 & $<0.0001$ \\
\hline Energy (kcal g-1) & $5990.4(2.92)$ & $5235.9(2.50)$ & $5047.3(2.52)$ & 106255 & $<0.0001$ \\
\hline
\end{tabular}


TABLE 2

Body mass, food intake, feces production, and digestive efficiency of foxes subject to three experimental diets. All values reported are on dry-weight, ash-free basis. Figures are mean \pm SD.

Masa corporal, ingesta de alimento, producción de fecas y eficiencia digestiva de zorros sujetos a tres dietas experimentales. Todos los valores son expresados como peso seco libre de ceniza. Los números son medias \pm DE.

\begin{tabular}{|c|c|c|c|c|}
\hline Diet & Rodent & Mixed & Fruit & F- and P-values \\
\hline Number of animals & 5 & 5 & 5 & \\
\hline Mass ( $\mathrm{g}$ at $\mathrm{t}=0$ day) & $4480 \pm 731$ & $6080 \pm 222$ & $5733 \pm 240$ & $\mathrm{~F}_{2,12}=2.35, \mathrm{P}=0.14$ \\
\hline Mass ( $\mathrm{g}$ at $\mathrm{t}=10$ days) & $5320 \pm 813$ & $6200 \pm 521$ & $3600 \pm 305$ & $\mathrm{~F}_{2,12}=5.18, \mathrm{P}=0.02$ \\
\hline F- and P-values & $\mathrm{F}_{1,8}=0.6, \mathrm{P}=0.42$ & $\mathrm{~F}_{1,8}=0.02, \mathrm{P}=0.87$ & $\mathrm{~F}_{1,8}=28.27, \mathrm{P}=0.0007$ & \\
\hline \multicolumn{5}{|l|}{ Food intake: } \\
\hline Dry-matter $\left(\mathrm{g} \mathrm{d}^{-1}\right)$ & $115.3 \pm 15.2$ & $218.9 \pm 60.4$ & $310.5 \pm 41.7 * *$ & $\mathrm{~F}_{2,10}=4.22, \mathrm{P}=0.04$ \\
\hline Energy $\left(\mathrm{kJ} \mathrm{d}^{-1}\right)$ & $2889.3 \pm 381.8$ & $5800.4 \pm 1599.7$ & $7521.6 \pm 1010.7 * *$ & $\mathrm{~F}_{2,10}=3.69, \mathrm{P}=0.06$ \\
\hline Nitrogen $\left(\mathrm{g} \mathrm{d}^{-1}\right)$ & $63.9 \pm 8.4$ & $56.9 \pm 15.7$ & $19.6 \pm 2.6^{* *}$ & $\mathrm{~F}_{2,10}=3.10, \mathrm{P}=0.09$ \\
\hline \multicolumn{5}{|l|}{ Feces production: } \\
\hline$\left(\mathrm{g} \mathrm{d}^{-1}\right)$ & $14.1 \pm 1.1$ & $102.6 \pm 28.5$ & $202.6 \pm 6.2 * *$ & $\mathrm{~F}_{2,10}=20.44, \mathrm{P}=0.0003$ \\
\hline$\left(\mathrm{kJ} \mathrm{d}^{-1}\right)$ & $197.8 \pm 16.3$ & $2756.1 \pm 750.3$ & $5134.8 \pm 157.4^{* *}$ & $\mathrm{~F}_{2,10}=20.70, \mathrm{P}=0.0003$ \\
\hline Nitrogen $\left(\mathrm{g} \mathrm{d}^{-1}\right)$ & $6.5 \pm 0.4$ & $15.2 \pm 4.6$ & $25.6^{*}$ & $\mathrm{~F}_{1,8}=3.52, \mathrm{P}=0.097$ \\
\hline \multicolumn{5}{|l|}{ Apparent digestibility: } \\
\hline Dry matter $(\%)$ & $87.3 \pm 0.9$ & $53.4 \pm 1.3$ & $32.7 \pm 7.7 * *$ & $\mathrm{~F}_{2,10}=75.84, \mathrm{P}<0.0001$ \\
\hline Energy $(\%)$ & $92.9 \pm 0.5$ & $52.7 \pm 1.7$ & $29.6 \pm 8^{* *}$ & $\mathrm{~F}_{2,10}=92.67, \mathrm{P}<0.0001$ \\
\hline Nitrogen $(\%)$ & $89.3 \pm 1.3$ & $73.9 \pm 0.7$ & $-17.6^{*}$ & $\mathrm{~F}_{1,8}=105.47, \mathrm{P}<0.0001$ \\
\hline Digestible intake energy $\left(\mathrm{kJ} \mathrm{d}^{-1}\right)$ & $2691.6 \pm 367.8$ & $2042.3 \pm 299.6$ & $2386.7 \pm 893.3 * *$ & $\mathrm{~F}_{2,10}=0.57, \mathrm{P}=0.58$ \\
\hline Mean retention time $(\mathrm{h})$ & $28.2 \pm 1.6$ & $18.8 \pm 1.0$ & $12.0 \pm 0.7 * *$ & $F_{2,10}=37.14, P<0.0001$ \\
\hline
\end{tabular}

$*(=1$ individual $) ; *(=3$ individuals $)$

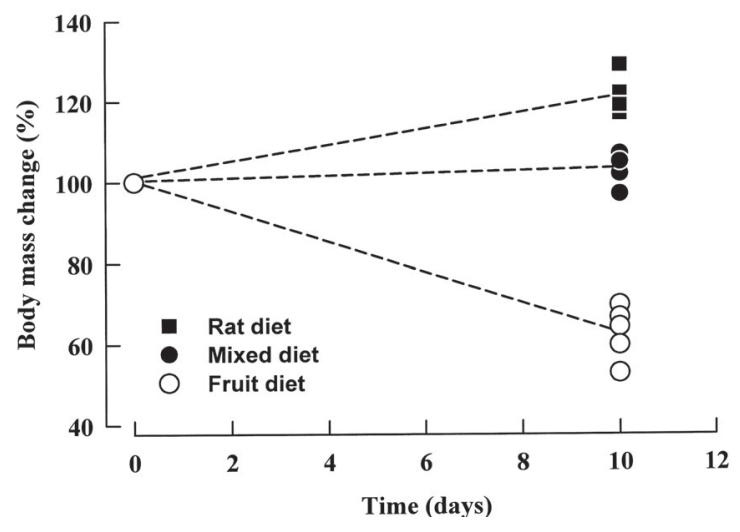

Fig. 1: Body mass balance through time in the culpeo fox as a function of different alternatives of food sources.

Balance de masas a través del tiempo en el zorro culpeo en función de diferentes fuentes de alimento.
Mean retention time was negatively and significantly correlated with dry-matter intake (Fig. 2). A higher intake of fruits, concomitant with a shorter mean retention time, may enable foxes to process more food per unit time. Nevertheless, this did not result in a higher digestibility or digestible energy intake in comparison to alternative food sources (see Table 2). Did the daily amount of food eaten, and food selected, vary inversely with mean retention time, or was it mean retention time that varied as a function of food eaten? Because these factors covary it is difficult to assign causality. Theoretically, a lower limit on fox capabilities to reduce retention time without compromising the nutritional/energetic budget is expected (Penry 1993). Indeed, we observed a $37 \%$ decrease in body mass among foxes on fruit diets and a $46 \%$ 
decrease in foxes without food. These data are in agreement with previous records on mass loss in other starved carnivores (Ball \& Golightly 1992, Prestrud \& Nilssen 1992, Fuglei \& Øristland 1999), as well as with records from Pseudalopex culpaeus during periods of low availability of mammalian prey and high consumption of fruit items (Castro et al. 1989, Jiménez et al. 1995, Salvatori et al. 1999).

Mixed diet may yield higher assimilation efficiencies and hence higher nutrient intakes than those predicted from the ingestion and assimilation of pure diets (Bjorndal 1991). We found that foxes did well on mixed diet (Table 2), and thus we hypothesize that during nutritional bottlenecks (low availability of mammalian prey) a mixed diet should yield a positive energy/mass balance for the fox at the field. The minimum values of dry-matter, energy, and nitrogen intake of mixed diets are about $210 \mathrm{~g} \mathrm{day}^{-1}, 1500 \mathrm{~kJ}$ $\mathrm{day}^{-1}$, and $25 \mathrm{~g} \mathrm{day}^{-1}$, respectively, theoretically allowing foxes to survive for at least ten days. On a rat diet, a fox should be able to meet its basic requirements with a dry-mass intake of $70 \mathrm{~g} /$ day or a wet-mass intake of about $123 \mathrm{~g} \mathrm{day}^{-1}$ (Fig. 3). These values are lower than those reported by Johnson (1992), i.e., 432-1194 $\mathrm{g} \mathrm{day}^{-1}$. Thus, temporal and spatial variation in nutrient, energy, and water contents of prey available in a given habitat may have an important effect on fox nutrition, energy use, and mass balance. What is clear, though, is that this fox species cannot survive feeding exclusively fruits for over a week.

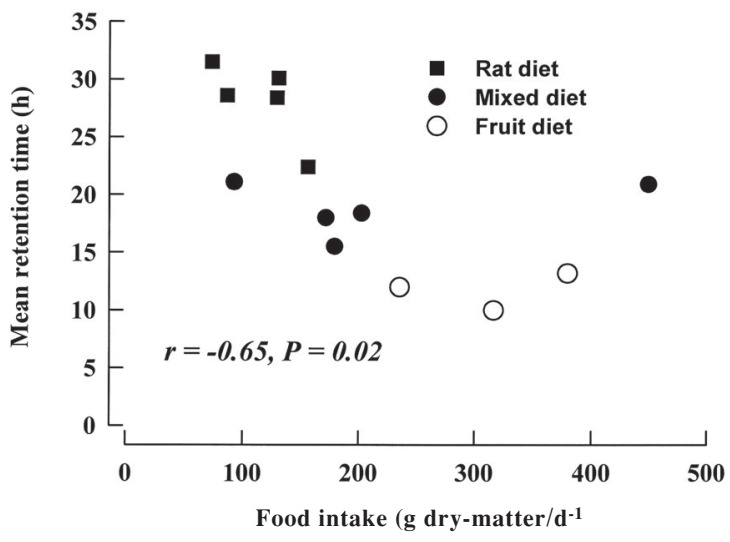

Fig. 2: Relationships between ad libitum daily dry-matter intake and mean retention time in relation to experimental diets in the culpeo fox.

Relación entre ingesta diaria de materia seca ad libitum y tiempo de retención medio en relación a las dietas experimentales en el zorro culpeo.

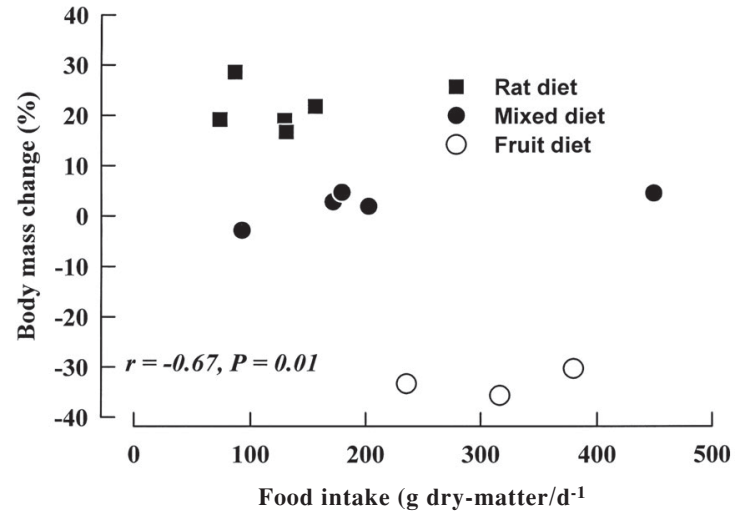

Fig. 3: Relationships between ad libitum daily dry-matter intake and body mass balance as a function of experimental diets in the culpeo fox.

Relación entre ingesta diaria de materia seca ad libitum y balance de masa corporal en función de las dietas experimentales en el zorro culpeo.

Why do foxes feed on such low-quality items as fruits? It may be argued that foxes are doing the best of a poor job and eating whatever is available when preferred prey abundance is low, even though it may not meet their most basic nutritional requirements. Foxes may be eating fruits just to satisfy their hunger. Alternatively, fruits may represent sources of water or yet unidentified vitamins or minerals (Bozinovic \& Martínez del Río 1996, Sabat \& Bozinovic 2000). In addition, fruit consumption may contribute to the associative effect that results from feeding on a mixed diet, because the nutritional value of dietary items may vary with the compounds with which it is consumed.

\section{ACKNOWLEDGMENTS}

Sergio Silva acknowledges a Ph.D. fellowship from CONICYT-Chile. We thank Chile's Corporación Nacional Forestal (CONAF), especially CONAF-IV Region, for allowing us to work at the Reserve and for providing logistic support. We are also grateful to Servicio Agricola y Ganadero (SAG) for issuing permits to trap animals. We thank E. Silva for laboratory and computer assistance. This research was supported by grant FONDECYT 298-0022 to SIS, a grant from the Andrew W. Mellon Foundation to FMJ, a FONDAP 1501-001 (Program $1 \& 2$ ) to FB 
and FMJ; and is dedicated to the memory of Mario Rosenmann.

\section{LITERATURE CITED}

AHLSTROM O, E FUGLEI \& LT MYDLAND (2003) Comparative nutrient digestibility of artic foxes (Alopex lagopus) on Svalbard and farm-raised blue foxes (Alopex lagopus). Comparative Biochemistry and Physiology A 134: 65-70.

AOAC (Asssociation of Official Analytical Chemists) (1980) Official methods of analytical chemists. Thirteenth edition. Association of Official Analytical Chemists, Washington, District of Columbia, USA. 469 pp.

ARMESTO JJ, R ROZZI, P MIRANDA \& C SABAG (1987) Plant/frugivore interactions in South American temperate forests. Revista Chilena de Historia Natural 58: 9-7.

BALL LC \& RT JR GOLIGHTLY (1992) Energy and nutrient assimilation by gray foxes on diets of mice and Himalaya berries. Journal of Mammalogy 73: 840-846.

BJORNDAL KA (1991) Diet mixing: nonaditive interactions of diet items in an omnivorous freshwater turtle. Ecology 72: 1234-1141.

BOSQUE C \& A PACHECO (2000) Dietary nitrogen as a limiting nutrient in frugivorous birds. Revista Chilena de Historia Natural 73: 441-450.

BOZINOVIC F (1995) Nutritional energetics and digestive responses of an herbivorous rodent (Octodon degus) to different levels of dietary fiber. Journal of Mammalogy 76: 627-637

BOZINOVIC F \& A MUÑOZ-PEDREROS (1995a) Nutritional ecology and digestive responses of an omnivorous-insectivorous rodent (Abrothrix longipilis) feeding on fungus. Physiological Zoology 68: 474-489.

BOZINOVIC F \& A MUÑOZ-PEDREROS (1995b) Dieta mixta y energética nutricional de un roedor micófago en el sur de Chile: interacciones entre ítemes dietarios. Revista Chilena de Historia Natural 68: 383-389.

BOZINOVIC F \& C MARTÍNEZ DEL RÍO (1996) Animals eat what they should not: why do they reject our foraging models? Revista Chilena de Historia Natural 69: 15-20.

BOZINOVIC F \& H TORRES-CONTRERAS (1998) Does digestion rate affect diet selection? A study in Octodon degus, a generalist herbivorous rodent. Acta Theriologica 43: 205-212.

CASTRO GC, N STOYAN \& JP MYERS (1989) Assimilation efficiency in birds: a function of taxon or food type? Comparative Biochemistry and Physiology A 92: 271-278.

CIPOLLINI ML (2000) Secondary metabolites of vertebratedispersed fruits: evidence for adaptative functions. Revista Chilena de Historia Natural 73: 421-440.

CORK SJ (1994) Digestive constraints on dietary scope in small and moderately-small mammals: how much do we really understand? In: Chivers DJ \& P Langer (eds) The digestive system in mammals: food, form and function: 337-369. Cambridge University Press, Cambridge, United Kingdom.

ELMHAGEN B, M TANNERFELDT, P VERUCCI \& A ANGERBJÖRN (2000) The arctic fox (Alopex lagopus): an opportunistic specialist. Journal Zoology, London 251: 265-276.
FELICETTI LA, CT ROBBINS \& LA SHIPLEY (2003) Dietary protein content alters energy expenditure and composition of the mass gain in Grizzly bears (Ursus arctos horribilis). Physiological and Biochemical Zoology 76: 256-261.

FOLEY WJ \& SJ CORK (1992) Use of fibrous diets by small herbivores: how far can the rules be "bent"? Trends in Ecology and Evolution 7: 159-162.

FUGLEI E \& NA ØRITSLAND (1999) Seasonal trends in body mass, food intake and resting metabolic rate, and induction of metabolic depression in arctic foxes (Alopex lagopus) at Svalbard. Journal Comparative Physiology B 169: 361-369.

GITTLEMAN JL (1989) Carnivore behavior, ecology and evolution. Comstock Publishing Associates, Cornell University Press, Ithaca, New York, USA. 620 pp.

GINSBERG JR \& DW MACDONALD (1990) Foxes, wolves, jackals, and dogs: an action plan for the conservation of canids. IUCN/SSC Canid Specialist Group and IUCN/SSC Wolf Specialist Group. International Union for Conservation of Nature and Natural Resources, Gland, Switzerland. 116 pp.

GREER JK (1965) Mammals of Malleco province, Chile. Michigan State University, Publications of the Museum, Biological Series 3: 49-152.

HERRERA CM (1984) Adaptation to frugivory of Mediterranean avian seed dispersers. Ecology 65: 609-617.

HERRERA CM (1987) Vertebrate-dispersed plants of the Iberian Peninsula: a study of fruit characteristics. Ecological Monographs 57: 305-331.

HERRERA CM (1998) Long-term dynamics of mediterranean frugivorous birds and fleshy fruits: a 12-year study. Ecological Monographs 68: 511-538.

HERRERA CM, P JORDANO, L LÓPEZ SORIA \& JA AMAT (1994) Recruitment of a mast-fruiting, birddispersed tree: bridging frugivore activity and seedling stablishment. Ecological Monographs 64: 315-344.

JAKSIC FM (1997) Ecología de los vertebrados de Chile. Ediciones Universidad Católica de Chile, Santiago, Chile. 262 pp.

JAKSIC FM, RP SCHLATTER \& JL YÁÑEZ (1980) Feeding ecology of central Chilean foxes, Dusicyon culpaeus and Dusicyon griseus. Journal of Mammalogy 61: 254-260.

JIMÉNEZ JE (1993) Comparative ecology of Dusicyon foxes at the Chinchilla National Reserve in northcentral Chile. Master of Sciences Thesis, University of Florida, Gainesville, Florida, USA. viii +163 pp.

JOHNSON WE (1992) Comparative ecology of the two sympatric South American foxes, Dusicyon culpaeus and D. griseus. Ph.D. Thesis, Iowa State University, Omas, Iowa, USA. 142 pp.

JOHNSON RA, MF WILLSON, JN THOMPSON \& RL BERTIN (1985) Nutritional values of wild fruits and consumption by migrant frugivorous birds. Ecology 66: 819-827.

KARASOV WH (1990) Digestion in birds: chemical and physiological determinants and ecological implications. In: Morrison ML, CJ Ralph, J Verner \& JR Jehl (eds) Avian foraging: theory, methodology, and applications. Studies in Avian Biology 13: 391-415. Cooper Ornithological Society, Lawrence, Kansas, USA.

KARASOV WH \& DJ LEVEY (1990) Digestive system trade-offs and adaptations of frugivorous passerine birds. Physiological Zoology 63: 1248-1270.

KIMBALL BA, DL NOLTE, RM ENGEMAN, JJ JOHNSTON \& FR STERMITZ (1998) Chemically 
mediated foraging preference of black bears (Ursus americanus). Journal of Mammalogy 79: 448-456.

LANDERS JN, TT FENDLEY \& AS JOHNSON (1977) Feeding ecology of wood ducks in South Carolina. Journal of Wildlife Management 41: 118-127.

LEVEY DJ \& WH KARASOV (1989) Digestive responses of temperate birds switched to fruit or insect diets. Auk 106: 675-686.

LEVEY DJ \& A GRAJAL (1991) Evolutionary implications of fruit processing limitations in Cedar Waxwing. American Naturalist 138: 171-189.

LITVAITIS JA \& WW MAUTZ (1980) Food and energy use by captive coyotes. Journal of Wildlife Management 44: 56-61.

MARTÍNEZ DEL RÍO C (1994) Nutritional ecology of fruit-eating and flower-visiting birds and bats. In: Chivers DJ \& P Langer (eds) The digestive system in mammals: food, form and function: 103-127. Cambridge University Press, Cambridge, United Kingdom.

McNAB BK (1995) Energy expenditure and conservation in frugivorous and mixed-diet carnivorans. Journal of Mammalogy 76: 206-222.

MCNAB BK (2002) The physiological ecology of vertebrates. Cornell University Press, Ithaca, New York, USA. 576 pp.

MEDEL RG \& FM JAKSIC (1988) Ecología de los cánidos sudamericanos: una revisión. Revista Chilena de Historia Natural 61: 67-79.

MESERVE PL, EJ SHADRICK \& DA KELT (1987) Diet and selectivity of two Chilean predators in the northern semi-arid zone. Revista chilena de Historia Natural 60: 93-99.

MILLER S \& J ROTTMANN (1976) Guía para el reconocimiento de mamíferos chilenos. Editora Nacional Gabriela Mistral, Santiago, Chile. 200 pp.

MOORS PJ (1977) Studies of the metabolism, food consumption and assimilation efficiency of a small carnivore, the weasel (Mustela nivalis L.). Oecologia 27: 185-202.

PENNINGS SC, MT NADEAU \& VJ PAUL (1993) Selectivity and growth of the generalist herbivore Dalabella auricularia feeding upon complementary resource. Ecology 74: 879-890.
PENRY DL (1993) Digestive constraints on diet selection. In: Hughes RN (ed) Diet selection: an interdisciplinary approach to foraging behaviour: 32-55. Blackwell Scientific Publications, Oxford, United Kingdom.

PRESTRUD P \& K NILSSEN (1992) Fat deposition and seasonal variation in body composition of arctic foxes in Svalbard. Journal Wildlife Management 56: 221-233.

RODE KD \& CT ROBBINS (2000) Why bears consume mixed diet during fruit abundance. Canadian Journal Zoology 78: 1640-1645.

SABAT P \& F BOZINOVIC (2000) Digestive plasticity and the cost of acclimation to dietary chemistry in the omnivorous leaf-eared mouse Phyllotis darwini. Journal of Comparative Physiology B 170: 411-417.

SILVA SI (2001) Ecología trófica y nutricional del zorro culpeo (Pseudalopex culpaeus): restricciones digestivas y energéticas asociadas a la frugivoría y sus efectos sobre la dispersión de semillas. Ph.D. Thesis, Facultad de Ciencias Biológicas, Pontificia Universidad Católica de Chile, Santiago, Chile. 120 pp.

STATISTICA (1997) Statistica release 5 (quick reference) for the Windows 95 operating system, 3rd edn. StatSoft, Tulsa, Oklahoma, USA.

TORRES-CONTRERAS H \& F BOZINOVIC (1997) Food selection in an herbivorous rodent: balancing nutrition with thermoregulation. Ecology 78: 22302237.

VOGTSBERGER LM \& GW BARRETT (1973) Bioenergetics of captive red foxes. Journal of Wildlife Management 37: 495-500.

WARNER ACY (1981) Rate of passage of digesta through the gut of mammals and birds. Nutritional Abstract Review 51B: 789-820.

WELCH CA, J KEAZ, KC KENDALL \& CT ROBBINS (1997) Constraints on frugivory by bears. Ecology 78: 1105-1119.

WESTOBY M (1978) What are the biological bases of varied diets? American Naturalist 112: 627-631.

YÁÑEZ J \& F JAKSIC (1978) Rol ecológico de los zorros (Dusicyon) en Chile central. Anales del Museo de Historia Natural de Valparaíso (Chile) 37: 113-116. 